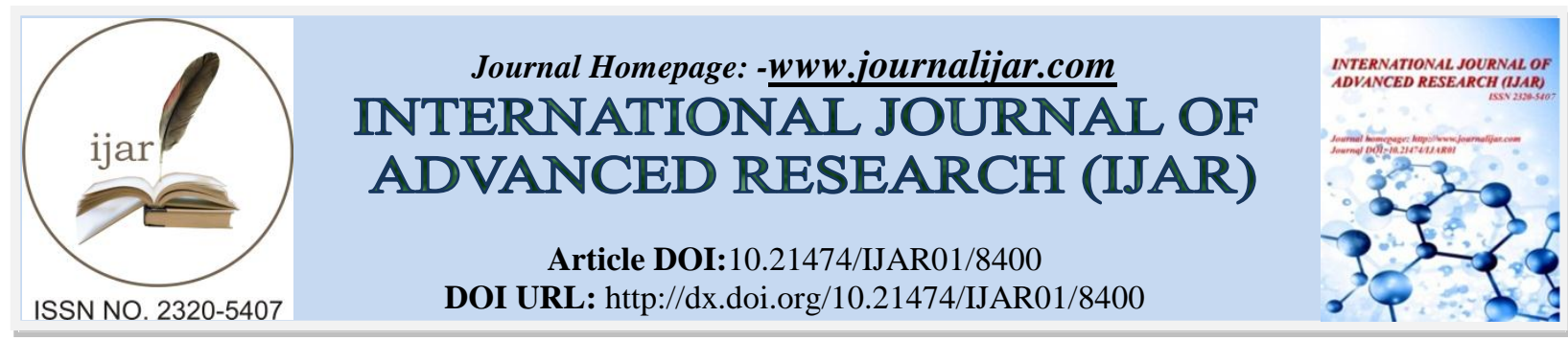

RESEARCH ARTICLE

\title{
EVALUATION OF A PANEL OF IHC MARKERS IN DIFFERENTIATION OF EXTRANODAL MALIGNANT SMALL ROUND CELL TUMORS.
}

Deepshikha ${ }^{1}$, Meenu Gill ${ }^{2}$, Gaurav Sharma ${ }^{3}$ Sumiti Gupta ${ }^{2}$, Promil Jain ${ }^{4}$, Veena Gupta ${ }^{2}$ and Rajeev Sen ${ }^{5}$.

1. Demonstrator, Deptt. of Pathology, Pt. B. D. Sharma, UHS, Rohtak.

2. Professor, Deptt. of Pathology, Pt. B. D. Sharma, UHS, Rohtak.

3. Ex Demonstrator, Deptt. of Forensic Medicine, Pt. B. D. Sharma, UHS, Rohtak.

4. Asst. Professor, Deptt. of Pathology, Pt. B.D. Sharma, UHS, Rohtak.

5. Sr. Professor \& Head, Deptt. of Pathology, Pt. B. D. Sharma, UHS, Rohtak.

\section{Manuscript Info}

\section{Manuscript History}

Received: 12 November 2018

Final Accepted: 14 December 2018

Published: January 2019

\section{Key words:-}

Malignant small round cell tumor, immunohistochemistry, differential diagnosis.

\begin{abstract}
Background: The small round cell tumors are a heterogeneous group of malignant neoplasms. Immunohistochemistry (IHC) has proven to be a significant tool in the identification as well as differentiation of tumors which become a diagnostic challenge on the basis of routine haematoxylin and eosin ( $\mathrm{H} \& \mathrm{E})$ stain alone. The aim of present study was to study the histomorphological spectrum of extranodal malignant small round cell tumors and to study the significance of a primary panel (LCA, CK, S-100 and Vimentin) and secondary panel of IHC markers in differential diagnosis of such tumors.

Methods: The study was carried out in the Department of Pathology, Pt. B.D. Sharma, UHS, Rohtak. A total of 60 cases of malignant small round cell tumors were selected for IHC and they were classified and categorized accordingly after IHC.

Results: Out of the 60 cases of malignant small round cell tumors, there were 19 cases $(31.6 \%)$ of small cell carcinoma, 16 cases (26.6\%) of non Hodgkin lymphoma, 5 cases $(8.3 \%)$ each of Ewing's sarcoma and PNET, 4 cases $(6.7 \%)$ of medulloblastoma, 3 cases $(5 \%)$ each of rhabdomyosarcoma and seminoma and 1 case (1.7\%) each of mesothelioma, neuroblastoma, small cell osteosarcoma, Wilm's tumor and poorly differentiated round cell tumor.

Conclusion: Immunohistochemistry has played a valuable adjunctive role for routine hematoxylin and eosin staining in the adequate and accurate categorization of small round cell tumors.
\end{abstract}

Copy Right, IJAR, 2017,. All rights reserved.

\section{Introduction:-}

In histopathology, a small round blue cell tumor is any one of a group of malignant neoplasms that have a characteristic appearance under the microscope, i.e. consisting of small round cells that stain blue on routine haematoxylin \& eosin (H\&E) stained sections and have scanty cytoplasm. They typically represent undifferentiated cells. ${ }^{1}$

Corresponding Author:-Deepshikha.

Address:-Demonstrator, Deptt. of Pathology, Pt. B. D. Sharma, UHS, Rohtak. 
There is a histological similarity and lack of differentiating features on H\&E sections in most of the small round cell tumors which makes the definite diagnosis extremely difficult and so immunohistochemical (IHC) and molecular studies act as an additional support. Diagnosis can be made in about 80-90\% of cases on H\&E stained slides coupled with IHC. However, in about 15-20\% of cases there is still a need for molecular or electron microscopic diagnosis. The spectrum of small round cell tumors comprises non-Hodgkin lymphoma (NHL); germ cell tumor; sarcomas which further include Ewing's sarcoma/primitive neuroectodermal tumor (ES/PNET), rhabdomyosarcoma, poorly differentiated synovial sarcoma, small cell osteosarcoma and leiomyosarcoma; malignant melanoma (small cell variant); blastomas which further include neuroblastoma, Wilm's tumor (nephroblastoma), hepatoblastoma, retinoblastoma and medulloblastoma; carcinoid tumor; mesothelioma; hybrid oncocytoma; small cell carcinoma; desmoplastic small round cell tumor (small cell variant) and merkel cell carcinoma. It is therefore, imperative to determine whether the small round cell tumor is epithelial, mesenchymal, neuroendocrine, melanocytic or hematopoietic in nature for treatment purposes as well as for the prognostic evaluation of the tumor. ${ }^{2}$

Several monoclonal antibodies have been developed, that detect different epitopes of the antigens which are present in the tumor cells. However, there is no antibody which is specific for a single tumor type and the pathologist has to judiciously correlate the clinical, radiological and the morphological findings with a panel of immumohistochemical (IHC) markers. The immunohistochemical profiling of the tumor may be done according to the anatomical location, microscopic features and other aspects of their clinical presentations, which all have a strong influence on the relative likelihood of a diagnosis. ${ }^{3}$

\section{Material And Methods:-}

The present prospective study was conducted in the Department of Pathology, Pt. B. D. Sharma, PGIMS, Rohtak. Formalin-fixed, paraffin-embedded sections of all the cases which were diagnosed as small round-cell tumors on small biopsies and resected specimens were retrieved from the files of the Department of Pathology, Pt. B. D. Sharma, UHS, Rohtak. A total of 60 cases were taken for this study. Haematoxylin and eosin stained sections of all the study cases were retrieved to confirm the tissue diagnosis and also the immunohistochemical stained sections obtained by using peroxidase anti-peroxidase method were studied to categorise the tumors. ${ }^{4}$

\section{Inclusion Criteria:-}

Small round cell tumors at all the extranodal sites only were included in the study.

\section{Exclusion Criteria:-}

Small round cell tumors of the lymph node were excluded from the study.

The primary panel of IHC markers which were used in the study to differentiate and categorise the small round blue cell tumors was LCA, CK, S-100 and Vimentin. According to their results, secondary panel of IHC markers were applied for further sub-classification of these tumors. The secondary panel of IHC markers included PLAP, CD117, CD30, CD20, CD10, CD5, Bc12, Bc16, PAX5, CD56, TTF1, P63, CD34, WT1, Tdt, CD79a, EGFR, Vwf, Ki67, CD99, EMA, CK, vimentin, myogenin, desmin, S-100, calretinin, NSE, chromogranin and synaptophysin. In the present study, weak/moderate/strong staining was considered as positive staining and equivocal staining was considered as negative staining.

\section{Results:-}

Out of the 60 cases of extranodal malignant small round cell tumor, the most common tumor was small cell carcinoma (19 cases, 31.6\%) followed by Non-Hodgkin lymphoma (16 cases, 26.6\%). The distribution of the small round cell tumors in the present study based on the final histopathological diagnosis is given in Table 1. Among the 60 cases, $45(75 \%)$ were male patients and $15(25 \%)$ were female patients. In our study, age range of the patients was between 2-85 years. Mean age of presentation was 40.8 years. The youngest patient was 2 years old and oldest was 85 years of age. Maximum number of cases $(n=16,26.7 \%)$ belonged to the age group of 51-60 years. Small cell carcinoma cases were seen maximum $(n=10)$ in the age group of 51-60 years, non Hodgkin lymphoma were seen maximum $(n=5)$ in 41-50 years. Ewing's sarcoma cases were predominantly seen in age group of 11-20 years while PNET cases were seen in age group of 11-30 years, medulloblastoma in age group of 0-20 years and rhabdomyosarcoma were seen in 11-20 years of age. Small cell carcinoma cases $(n=19)$ were seen predominantly in males, non Hodgkin lymphoma cases $(n=16)$ were seen to have equal distribution in males and females, Ewing's sarcoma was seen predominantly in males while PNET cases were seen to have a male: female ratio of 1:1.5, 
rhabdomyosarcoma was seen in males predominantly and rest of the categories seemed to have a male: female ratio of 1:1. Each of the tumor was adequately categorized using the appropriate antibody panel.

Table 1:-Distribution of the cases according to the histopathological diagnosis.

\begin{tabular}{|c|c|c|c|}
\hline No. & Type & No. of cases & Percentage (\%) \\
\hline 1 & Ewing's sarcoma & 5 & 8.3 \\
\hline 2 & Medulloblastoma & 4 & 6.7 \\
\hline 3 & Mesothelioma & 1 & 1.7 \\
\hline 4 & Neuroblastoma & 1 & 1.7 \\
\hline 5 & Non Hodgkin lymphoma & 16 & 26.6 \\
\hline 6 & Rhabdomyosarcoma & 3 & 5.0 \\
\hline 7 & Seminoma & 3 & 31.6 \\
\hline 8 & Small cell carcinoma & 19 & 1.7 \\
\hline 9 & Small cell osteosarcoma & 1 & 1.7 \\
\hline 10 & Wilm's tumor & 1 & 8.3 \\
\hline 11 & PNET & 5 & 1.7 \\
\hline 12 & Poorly differentiated round cell tumor & 1 & $\mathbf{1 0 0 . 0}$ \\
\hline & Total & $\mathbf{6 0}$ & \\
\hline
\end{tabular}

In the present study, $36.6 \%(\mathrm{n}=22)$ of the cases were diagnosed with the help of morphological features, clinical history, location of the tumor and primary panel of IHC markers; although secondary panel was applied for all these cases for their further typing, while $61.7 \%(n=37)$ cases required the further application of secondary panel of IHC markers for making a definitive diagnosis. Only $1.7 \%(\mathrm{n}=1)$ cases were there which were inconclusive even after the application of secondary panel of IHC markers (Table $2 \& 3$ ).

Table 2:-Cases diagnosed on the basis of primary panel of IHC markers.

\begin{tabular}{|c|c|c|c|c|c|c|c|c|}
\hline \multirow{2}{*}{ Morphology } & \multirow{2}{*}{ Location } & \multicolumn{4}{|c|}{ Primary panel of IHC marker } & \multirow{2}{*}{ Final diagnosis } & \multirow{2}{*}{$\begin{array}{l}\text { No of } \\
\text { cases }\end{array}$} & \multirow[t]{2}{*}{$\%$} \\
\hline & & CK & Vimentin & S-100 & LCA & & & \\
\hline $\begin{array}{l}\text { Small round } \\
\text { cell }\end{array}$ & $\begin{array}{c}\text { Extranodal } \\
\text { variable } \\
\text { sites }\end{array}$ & $\mathrm{Neg}$ & Neg & $\mathrm{Neg}$ & Pos & $\begin{array}{l}\text { Non Hodgkin } \\
\text { lymphoma }\end{array}$ & 16 & 72.8 \\
\hline $\begin{array}{l}\text { Small round } \\
\text { cell }\end{array}$ & Kidney & Pos & Pos & Neg & Neg & Wilm's tumor & 1 & 4.5 \\
\hline $\begin{array}{l}\text { Small round } \\
\text { cell }\end{array}$ & $\begin{array}{l}\text { Posterior } \\
\text { fossa }\end{array}$ & Neg & Neg & Neg & Neg & Medulloblastoma & 4 & 18.2 \\
\hline $\begin{array}{l}\text { Small round } \\
\text { cell }\end{array}$ & $\begin{array}{c}\text { Right } \\
\text { clavicular } \\
\text { mass }\end{array}$ & Pos & Pos & Neg & Neg & $\begin{array}{c}\text { Small cell } \\
\text { osteosarcoma }\end{array}$ & 1 & 4.5 \\
\hline Total & & & & & & & 22 & 100.0 \\
\hline
\end{tabular}

Table 3:-Cases diagnosed on the basis of application of secondary panel of IHC markers.

\begin{tabular}{|c|c|c|c|c|c|c|c|c|}
\hline \multirow{2}{*}{ Morphology } & \multicolumn{4}{|c|}{ Primary panel of IHC marker } & \multirow{2}{*}{$\begin{array}{l}\text { Secondary panel } \\
\text { of IHC marker }\end{array}$} & \multirow{2}{*}{ Final diagnosis } & \multirow{2}{*}{$\begin{array}{l}\text { No. } \\
\text { of } \\
\text { cases }\end{array}$} & \multirow[t]{2}{*}{$\%$} \\
\hline & CK & Vimentin & $\begin{array}{c}\text { S- } \\
100\end{array}$ & LCA & & & & \\
\hline $\begin{array}{l}\text { Small round } \\
\text { cell }\end{array}$ & Pos & Neg & $\mathrm{Neg}$ & Neg & $\begin{array}{c}\text { Positive for } \\
\text { Synaptophysin/ } \\
\text { NSE/ } \\
\text { Chromogranin/ } \\
\text { CD56/ TTF1/ P63/ } \\
\text { EGFR }\end{array}$ & Small cell carcinoma & 19 & 51.4 \\
\hline $\begin{array}{c}\text { Small round } \\
\text { cell }\end{array}$ & Pos & $\mathrm{Neg}$ & Neg & $\mathrm{Neg}$ & Calretinin/WT1 & Mesothelioma & 1 & 2.7 \\
\hline $\begin{array}{c}\text { Small round } \\
\text { cell }\end{array}$ & Pos & Neg & $\mathrm{Neg}$ & Neg & PLAP/ CD117 & Germ cell tumor & 3 & 8.1 \\
\hline Small round & Neg & Pos & $\mathrm{Neg}$ & Neg & CD99/ PAS/ & Ewing's sarcoma & 5 & 13.5 \\
\hline
\end{tabular}




\begin{tabular}{|c|c|c|c|c|c|c|c|c|}
\hline cell & & & & & CD117 & & & \\
\hline $\begin{array}{l}\text { Small round } \\
\text { cell }\end{array}$ & Neg & Pos & Neg & Neg & $\begin{array}{c}\text { Desmin } \\
\text { /myogenin }\end{array}$ & Rhabdomyosarcoma & 3 & 8.1 \\
\hline $\begin{array}{l}\text { Small round } \\
\text { cell }\end{array}$ & Neg & Pos & Neg & Neg & CD99 & PNET & 5 & 13.5 \\
\hline $\begin{array}{l}\text { Small round } \\
\text { cell }\end{array}$ & Neg & $\mathrm{Neg}$ & Pos & Neg & $\begin{array}{c}\text { NSE/ } \\
\text { Chromogranin }\end{array}$ & Neuroblastoma & 1 & 2.7 \\
\hline Total & & & & & & & 37 & 100.0 \\
\hline
\end{tabular}

\section{Discussion:-}

Differential diagnosis of small round cell tumors, frequently constitutes a difficult diagnostic problem. Accurate diagnosis of these tumors is essential because the treatment options, responses to therapy and prognosis vary widely depending on the diagnosis. A careful examination of the $\mathrm{H} \& \mathrm{E}$ sections of the well sampled tumors along with the clinical history, anatomical site and radiological findings can be coupled with a suitable panel of IHC markers and all these can be integrated to arrive at a conclusive diagnosis. Immunohistochemistry should always be used as an adjunct to the morphology, to avoid an erroneous diagnosis. This prospective study was conducted in the Department of Pathology, Pt. B.D. Sharma, UHS, Rohtak with the aim to study the histomorphological spectrum of extranodal malignant small round cell tumors and to study the significance of primary panel and secondary panel of immunohistochemical markers in the diagnosis and categorization of small round cell tumors. The study group included 60 cases of extranodal malignant small round cell tumors.

In our study, age range of the patients was between 2-85 years. Mean age of presentation was 40.8 years. The youngest patient was 2 years old and oldest was 85 years of age. Maximum number of cases $16(26.7 \%)$ belonged to the age group of 51-60 years. In the study conducted by Bhagat et $\mathrm{al}^{5}$, out of 50 cases, maximum number of cases were in the age group of 41-50 years (28\%) and their ages ranged from 3-80 years with the mean age of 40 years. Likewise, the sex distribution and male:female ratio in our study was in concordance with various studies conducted before by Ashraf et $\mathrm{al}^{6}$, Bhagat et $\mathrm{al}^{7}, \mathrm{D}^{\prime} \mathrm{Cruze}$ et $\mathrm{al}^{8}$ and Patel RG et $\mathrm{al}^{9}$. The present study, as well as, most of the previous studies show that males are affected more commonly than females.

Our study was in concordance with the study conducted by Ashraf et $\mathrm{al}^{6}$ in that the maximum number of cases were of small cell carcinoma (19.4\%) followed by non Hodgkin lymphoma cases (16.7\%). But studies conducted by Patel RG et $\mathrm{al}^{9}$. Patel A et $\mathrm{al}^{10}$, Patel MM et $\mathrm{al}^{11}$, D'Cruze et $\mathrm{al}^{8}$ and Bashyal et $\mathrm{al}^{2}$ on malignant small round cell tumors showed maximum incidence of non Hodgkin lymphoma. This was probably, because they have included nodal as well as extranodal cases of non Hodgkin lymphoma in their studies while in the present study, only extranodal NHL cases were included and nodal NHL cases were excluded from the present study.

In the present study, small cell carcinoma $(n=19,31.6 \%)$ constituted the most predominant type of malignant small round cell tumor with the respiratory tract being the most common site (17 cases). The second most common type of extranodal malignant small round cell tumor were the non Hodgkin lymphoma cases $(n=16,26.6 \%)$ with stomach (3 cases) as the most common site. Our study was in concordance with the study conducted by Pity IS ${ }^{12}$ in that the most common site of malignant small round cell tumor in their study was also the respiratory tract $(n=30,23.6 \%)$. In the study conducted by Patel $\mathrm{A}$ et $\mathrm{al}^{10}$, the most common site of extranodal non Hodgkin lymphoma was also stomach, which is in agreement with our study.

In the present study, 24 out of 60 cases were CK positive on primary panel which were then subjected to secondary panel of IHC markers. Among these, 19 cases were positive for synaptophysin, chromogranin, NSE, CD56 and p63 and were diagnosed as small cell carcinoma. Rest of the CK positive cases included 2 cases which were positive for PLAP and CD117 and, so were diagnosed as germ cell tumor; 1 case of mesothelioma which showed positivity for calretinin and WT1; 1 case which was positive for vimentin, WT1 and desmin was diagnosed as Wilm's tumor and 1 case of small cell osteosarcoma which showed positive expression on application of vimentin, CD99 and CD117. Although the diagnosis of Wilm's tumor and small cell osteosarcoma was made on the basis of morphology, location of the tumor, age, clinical features and primary panel of IHC markers but other IHC markers were applied to confirm the diagnosis. In a study conducted by Patel MM et $\mathrm{al}^{11}$, Patel RG et $\mathrm{al}^{9}$, Patel A et $\mathrm{al}^{10}$, D'Cruze et al ${ }^{8}$ and Pity IS ${ }^{12}$ they found that $100 \%$ cases of Wilm's tumor were positive for CK, vimentin and WT1, thus correlating with our study. Patel MM et al ${ }^{11}$, Patel A et al ${ }^{10}$ and Pity $\mathrm{IS}^{12}$ showed $100 \%$ cases of seminoma to be PLAP and 
CD117 positive, thus in concordance with the present study. Also, they showed $92 \%$ cases of mesothelioma to be positive for calretinin, thus correlating with our study.

In our study, 13 cases out of a total of 60 cases were vimentin positive. On applying secondary panel of IHC markers, 8 of these were positive for CD99 and were diagnosed as Ewing's sarcoma/PNET. Rest of the vimentin positive cases included 3 cases of rhabdomyosarcoma which showed positivity for desmin and myogenin and 1 case each of small cell osteosarcoma and Wilm's tumor. Konrad P et al $^{13}$ showed $94.7 \%$ cases and Bashyal et al ${ }^{2}$ and Patel MM et al ${ }^{11}$ showed $100 \%$ cases of Ewing's sarcoma/ PNET to be positive for CD99, correlating with our study. Immunohistochemically, strong membrane staining for CD99 is consistently seen in almost all cases of Ewing's sarcoma/ PNET, although it is not very specific because it may also come positive in several other soft tissue sarcomas and lymphoblastic lymphomas. ${ }^{2}$ Konrad P et al ${ }^{13}$, Patel RG et al ${ }^{9}$, Patel A et al ${ }^{10}$, Ashraf et al ${ }^{6}$, Patel MM et $\mathrm{al}^{11}$, D'Cruze et $\mathrm{al}^{8}$ and Bashyal et $\mathrm{al}^{2}$ showed $100 \%$ cases of rhabdomyosarcoma to be positive for myogenin which correlates with our study. Vimentin positive cases of blastoma were further divided according to site and immunohistochemical profile. Nephroblastoma is the most common paediatric renal neoplasm. In the present study, 1 case of nephroblastoma was found to be positive for CK, vimentin and WT1. Patel MM et al ${ }^{11}$ found $100 \%$ cases of Wilm's tumor to be positive for CK and vimentin, correlating with our study.

There were only 2 cases out of the 60 cases which were S-100 positive, one of these was positive for NSE and chromogranin but was negative for CD99 and so, was diagnosed as neuroblastoma whereas the other case was also vimentin positive and remained inconclusive despite application of multiple markers. Neuroblastoma shows immunoreactivity with NSE, synaptophysin and chromogranin. ${ }^{2}$ Our findings are consistent with the study conducted by Patel MM et $\mathrm{al}^{11}$.

In the present study, there were 16 cases which were positive for LCA (CD45) out of the 60 cases of extranodal malignant small round cell tumors and a diagnosis of NHL was made based on the morphological features and LCA positivity. But secondary panel was applied for further typing of the NHL cases. Among these, 13 (81.3\%) non Hodgkin lymphoma cases were positive for CD20, CD10, Bcl6 and were typed as B-cell NHL while 3 cases (18.7\%) were positive for CD5 and Tdt and were typed as T-cell NHL. CD45 (LCA) is a surface antigen expressed by virtually all hematolymphoid proliferations and monoclonal antibodies for this marker are reliably specific. ${ }^{2}$ Our study was in concordance with Konrad $\mathrm{P}$ et $\mathrm{al}^{13}$, Patel RG et $\mathrm{al}^{9}$, Patel A et al ${ }^{10}$, Ashraf et al ${ }^{6}$, Patel MM et al ${ }^{11}$, $\mathrm{D}^{\prime}$ Cruze et $\mathrm{al}^{8}$, Pity IS ${ }^{12}$ and Bashyal et $\mathrm{al}^{2}$. Our study and the previous studies showed that NHL cases show $100 \%$ positive expression for LCA and B-cell lymphomas are more common than T-cell lymphoma.

Table 4:-Comparision of various studies where IHC contributed to the diagnosis:-

\begin{tabular}{|l|l|l|l|l|}
\hline Study group & $\begin{array}{l}\text { Total cases in which } \\
\text { IHC was applied }\end{array}$ & Diagnosis on IHC & $\begin{array}{l}\text { Percentage of } \\
\text { diagnosed cases }(\%)\end{array}$ & $\begin{array}{l}\text { Percentage of } \\
\text { inconclusive cases } \\
(\%)\end{array}$ \\
\hline Shah et al $^{14}$ & 56 & 49 & 87.5 & 12.5 \\
\hline Ahmed et al $^{15}$ & 265 & 249 & 93.9 & 6.1 \\
\hline Pity IS $^{12}$ & 127 & 112 & 88.2 & 11.8 \\
\hline Bashyal et al $^{2}$ & 40 & 36 & 90 & 10 \\
\hline Bhagat et al $^{7}$ & 50 & 49 & 98 & 2 \\
\hline D'Cruze et al $^{8}$ & 40 & 40 & 100 & 0 \\
\hline Patel MM et al $^{11}$ & 80 & 77 & 96.3 & 3.7 \\
\hline Bhagat et al $^{5}$ & 74 & 73 & 98.6 & 1.4 \\
\hline Ashraf et al & 36 & 33 & 91.7 & 8.3 \\
\hline Patel A et al & 38 & 37 & 97.4 & 2.6 \\
\hline Present study & 60 & 59 & 98.3 & 1.7 \\
\hline
\end{tabular}

Our study was in concordance with the study conducted by Bhagat et al ${ }^{5}$, D'Cruze et $\mathrm{al}^{8}$, Patel MM et al ${ }^{11}$, Ahmed et $\mathrm{al}^{15}$, Patel A et $\mathrm{al}^{10}$ and Ashraf et $\mathrm{al}^{6}$ (Table 4). So our study is well supported and shows the vital role of IHC in the differential diagnosis of extranodal malignant small round cell tumors. The studies conducted by Shah et al ${ }^{14}$ and Pity IS $^{12}$ showed a slightly higher proportion of cases which were left inconclusive even after IHC application ( $12.5 \%$ and $11.8 \%$ respectively). This could be probably, because of a limited number of IHC markers employed in their studies, limitations of the technique employed, antigen changes during tissue fixation or true absence of 
cellular differentiation, while the panel of IHC markers was exhaustive in rest of the studies. In cases, which are rendered inconclusive on morphology and IHC; electron microscopy, cytogenetic studies and molecular techniques may be helpful. These were out of scope in our present study because of their non-availability in our set-up.

Immunohistochemistry has emerged as a very valuable diagnostic tool to help in distinguishing the undifferentiated tumors especially small round cell tumors. Its advantages include its remarkable sensitivity and specificity, its applicability to routinely processed, formalin fixed material and compatibility to most of the common fixatives. Proper panel of IHC markers followed according to the guidelines is very useful which specifically saves both, tissue and time for the correct diagnosis and further typing. In some of the cases, IHC markers do not discriminate between neoplastic and non-neoplastic lesions. The distinction in such cases has to be made by conventional histopathological morphology which is must as a primary screening for all the cases. The immunohistochemistry needs to be applied routinely for undifferentiated tumors in the diagnostic histopathology. This, of course, needs to be supplemented by the use of cytogenetic studies such as fluorescent in situ hybridization (FISH) whenever required and available with a firm realization that all these are invaluable adjuncts to meticulous gross and microscopic examination, but cannot replace them.

\section{Conclusion:-}

The small round cell tumors are a heterogeneous group of malignant neoplasms. Immunohistochemistry represents a cost effective and rapid tool that can provide us a clear distinction among the various types of small round cell tumors. Its purpose is to categorise the patients so that an appropriate and a specific treatment can be ensured, as well as to identify those cases which are at a higher risk of recurrence and fatal outcomes, so that timely measures can be taken. A panel approach which comprises of carefully selected antibodies should always be there, so that an antigenic profile of positive as well as negative markers can be made and this will provide the most accurate characterization of tumor. Our study showed that the use of immunohistochemistry was extremely beneficial in the categorization of small round cell tumors. It must be performed at a high standard, so that the results are meaningful and reproducible. Molecular techniques and electron microscopy should be integrated selectively in future at the discretion of the pathologist to provide rapid and comprehensive solutions for inconclusive cases.

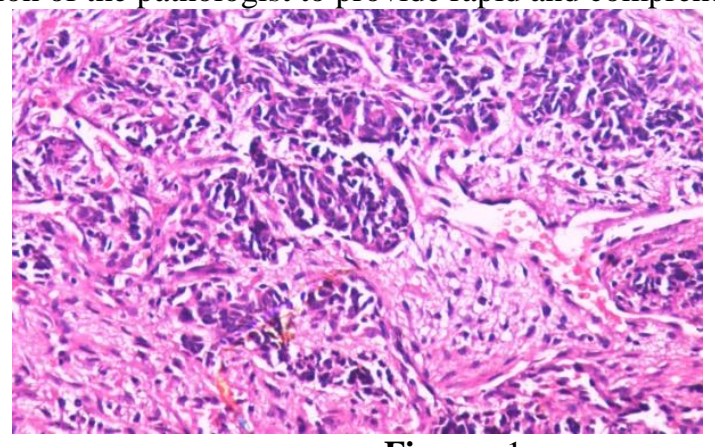

Figure:-1a

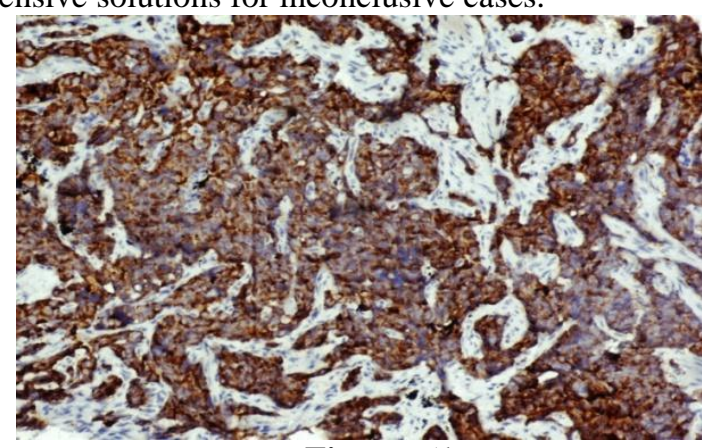

Figure:-1b

Figure 1a:-A case of small cell carcinoma arising from the respiratory tract, showing hyperchromatic small round tumor cells. (H\&E,200X)

Figure 1b:-Small cell carcinoma showing positive expression of synaptophysin in tumor cells. (IHC, 200X)

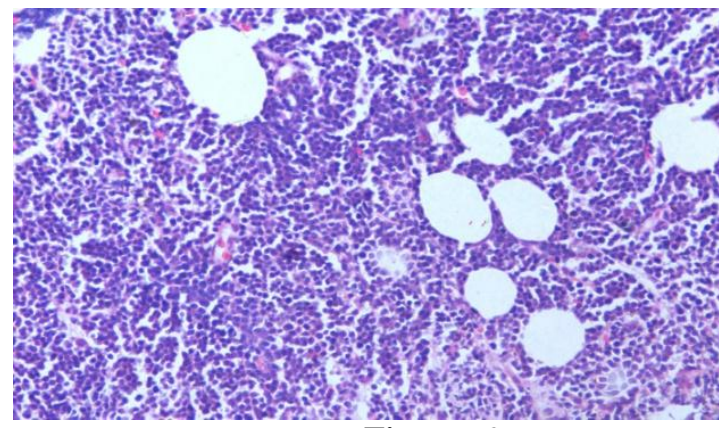

Figure:-2a

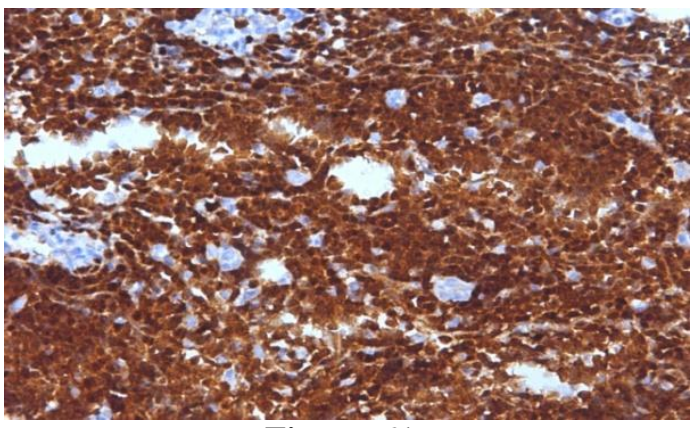

Figure:-2b

Figure 2a:-A case of Lymphoblastic lymphoma (T-cell type) presenting as a mediastinal mass. (H\&E, 200X) Figure 2b:-Lymphoblastic lymphoma, T-cell type showing positive expression of Tdt. (IHC, 200X) 


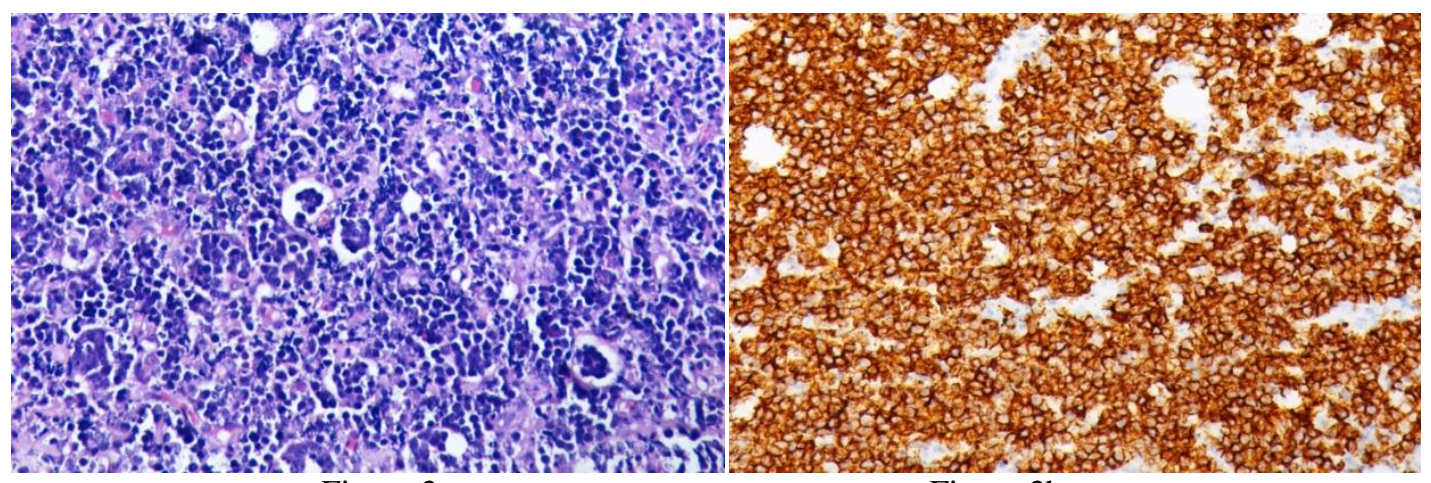

Figure 3a

Figure $3 b$

Figure 3a:-A case of extranodal non Hodgkin lymphoma (NHL) showing hyperchromatic small round cells. $(\mathrm{H} \& \mathrm{E}, 200 \mathrm{X})$

Figure 3b:-Case of NHL, B-cell type, showing positive CD20 expression. (IHC, 200X)

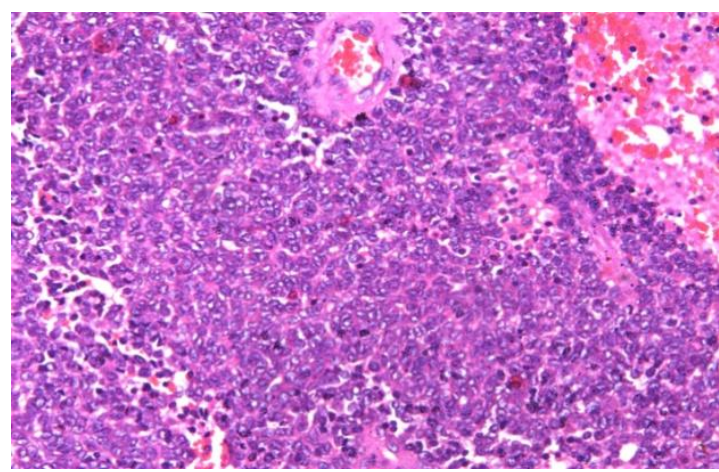

Figure:-4a

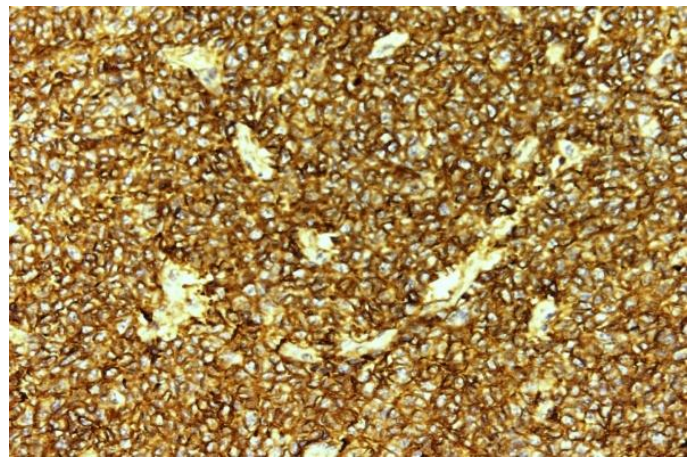

Figure:-4b

Figure 4a:-Ewing's sarcoma showing cells with uniform round nuclei. (H\&E, 200X)

Figure 4b:-Ewing's sarcoma showing positive expression of CD99 in tumor cells. (IHC, 200X)

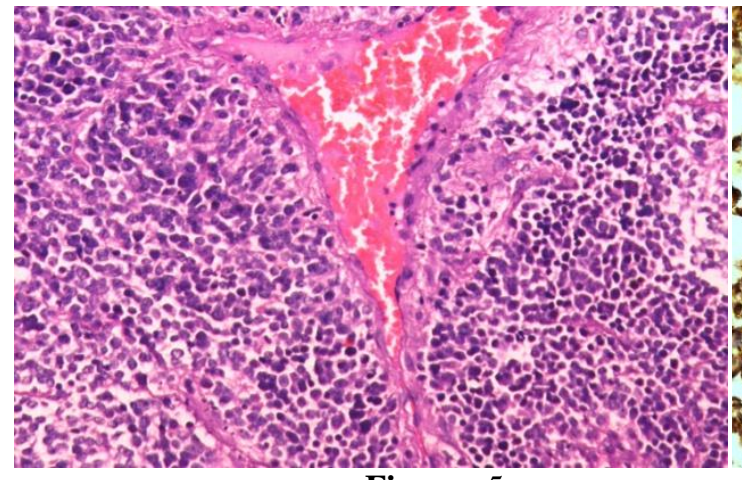

Figure:-5a

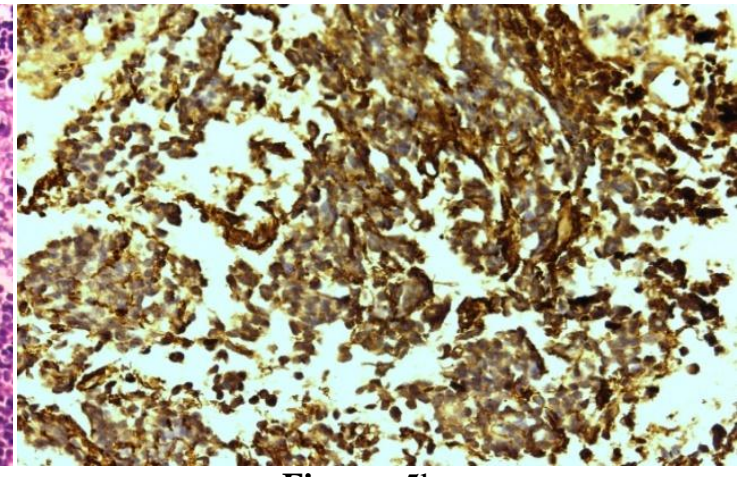

Figure:-5b

Figure 5a:-Medulloblastoma presenting as posterior fossa mass showing small round tumor cells. (H\&E, 200X) Figure 5b:-Medulloblastoma showing GFAP (Glial Fibrillary Acidic Protein) positive expression in tumor cells. (IHC, 200X) 


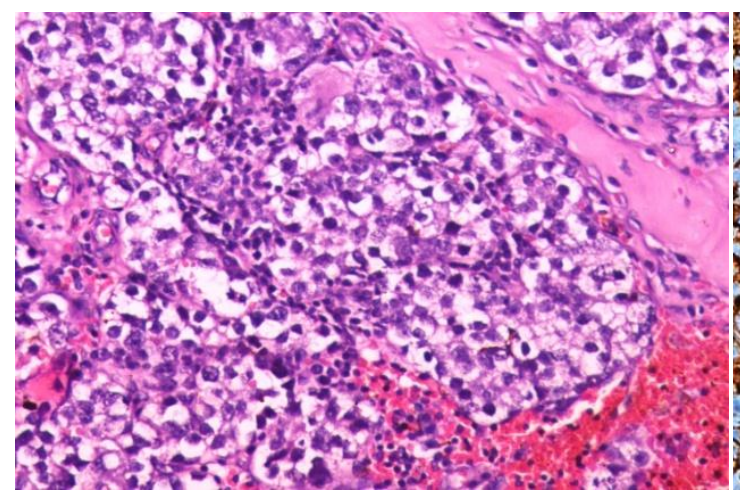

Figure:-6a

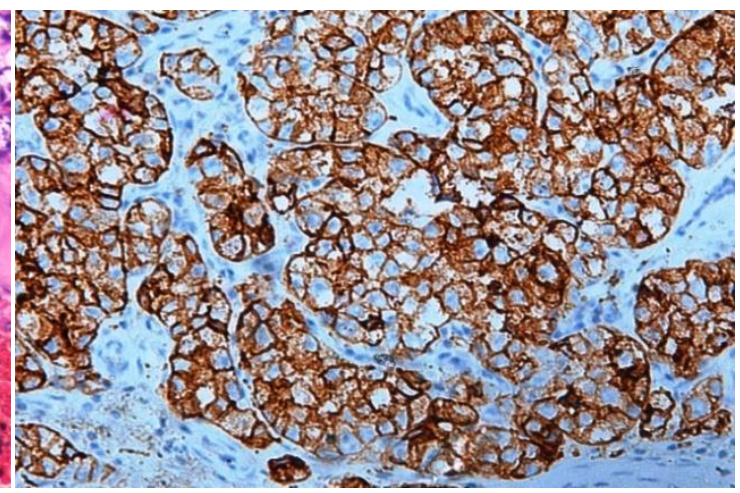

Figure:-6b

Figure 6a:-A case of seminoma involving left side testes, showing malignant small round tumor cells. (H\&E,200X) Figure 6b:-Case of seminoma showing positive expression of PLAP in tumor cells. (IHC, 200X)

\section{References:-}

1. Gregorio A, Corrias MV, Castriconi R, Dondero A, Mosconi M, Gambini C, et al. Small round blue cell tumors: diagnostic and prognostic usefulness of the expression of B7-H3 surface molecule. Histopathology. 2008;53(1):73-80.

2. Bashyal R, Pathak TB, Shrestha S, Pun CB, Banstola S, Neupane S, et al. Role of immunohistochemistry in the diagnosis of malignant small round cell tumors. J Pathol Nepal. 2011;1(2):87-91.

3. Wick MR. Immunohistochemical approaches to the diagnosis of undifferentiated malignant tumors. Ann Diagn Pathol. 2008;12:72-84.

4. Jackson P, Blythe D. Immunohistochemical techniques. In: Bancroft JD, Gamble M, editors. Theory and practice of histologic techniques. $7^{\text {th }}$ ed. New York: Churchill Livingstone; 2012. p.381-426.

5. Bhagat VM, Patel AR, Modi JP, Saini PK, Tailor HJ, Kaptan KR. Immunohistochemistry: A diagnostic tool for accurate characterization of undifferentiated malignant tumors. Int J Med Sci Public Health. 2013;2(4):920-6.

6. Ashraf MJ, Beigomi L, Azarpira N, Geramizadeh B, Khademi B, Hakimzadeh A, et al. The small round blue cell tumors of the sinonasal area: Histological and immunohistochemical findings. Iran Red Crescent Med J. 2013 Jun;15(6):455-61.

7. Bhagat VM, Kaptan KR, Dudhat RB, Italiya SL, Tailor HJ, Patel AR. Adjunctive role of immunohistochemistry to traditional histomorphology in diagnosis and accurate typing of soft tissue sarcoma. Int J Med Sci Public Health. 2013;2(4):980-7.

8. D'cruze L, Dutta R, Rao S, Rao A, Varadarajan S, Kuruvilla S. The role of immunohistochemistry in the analysis of the spectrum of small round cell tumors at a tertiary care centre. J Clin Diagn Res. 2013 Jul;7:137782.

9. Patel RG, Shah PY, Prajapati SG, Amin NS, Khant VS. Histopathological study of round cell tumors- A retrospective study. Int J Med Sci Public Health. 2017;6(2):388-93.

10. Patel A, Patel M, Bhagat V, Naik K. Role of immunohistochemistry in the differential diagnosis of malignant small round cell tumor: a study of 38 cases. Int J Res Med Sci. 2015 Dec; 3(12):3833-9.

11. Patel MM, Dhandha ZB, Italiya SL, Shah MB, Kaptan KR, Mansuri BM. Role of immunohistochemistry in differential diagnosis of round cell tumor. Indian J Res. 2013;3(5): 217-20.

12. Pity IS. Histopathological and immunohistochemical approach for characterization of malignant round cell tumors. Zanco J Med Sci. 2010;14(1):144-50.

13. Konrad P, Cieckiewiczi AS, Pekuli M, Nowecki Z. Differential diagnosis of small round cell tumors(SRCT), fluorescence in situ hybridization(FISH) and immunohistochemistry study. Pol J Pathol. 2009;4:151-162.

14. Shah SH, Soomro IN, Siddiqui MS, Pervez S, Hassan SH. Immunohistochemical evaluation of small round cell tumors of childhood. J Pak Med Assoc. 1999 Apr;49(4):87-9.

15. Ahmed Z, Azad NS, Bhurgari Y, Ahmed R, Kayani N, Pervez S, et al. Significance of immunohistochemistry in accurate characterization of malignant tumors. J Ayub Med Coll Abbottabad. 2006;18:38-43. 